\title{
Kompetensi Manajerial Kepala Sekolah Dalam Meningkatkan Profesionalisme Guru
}

\author{
Muhammad Darwisy Al $\mathbf{M}^{1}$, Dewie Tri Wijayati $\mathbf{W}^{2}$, Soedjarwo \\ ${ }^{123}$ Universitas Negeri Surabaya, Indonesia \\ darwisy.19008@mhs.unesa.ac.id
}

\begin{abstract}
The objective of this research is how to know how is the application of the principal's managerial competence, such as supporting factors, and how the leadership gping in raising teachers' professionalism in SMAN 1 Pemekasan. This research used qualitative descriptive approach. The data collected by observing, interviewing and taking documentations. Based on the data analysis, it is concluded that (1) The application of the principal's leadership refered to three basic patterns, such as, planning, development and evaluation. (2) The factors that influenced its application are based on the internal and external factors. (3) The leadership style that had been applicated used democratic leadership style.
\end{abstract}

Keywords: Managerial Competencie, Principal, Professionalism of Teachers

\begin{abstract}
Abstrak. Tujuan penelitian ini adalah untuk mengetahui penerapan kompetensi manajerial kepala sekolah, tentang faktor-faktor pendukung, dan bagaimana gaya kepemimpinan dalam meningkatkan profesionalisme guru di SMAN 1 Pamekasan. Penelitian ini menggunakan pendekatan deskriptif kualitatif. Pengumpulan data menggunakan teknik observasi, wawancara dan dokumentasi. Berdasarkan hasil analisis maka diperoleh kesimpulan yang menjawab permasalahan penelitian ini yaitu: (1) Pelaksanaan kepemimpinan yang diterapkan kepala sekolah bahwasanya berpegang teguh pada tiga pola dasar, yakni perencanaan, pengembangan, dan evaluasi. (2) Faktor yang mempengaruhi kepemimpinan kepala sekolah dalam meningkatkan profesionalisme guru berlandaskan dari faktor internal dan faktor eksternal. (3) Gaya kepemimpinan yang diterapkan oleh kepala sekolah adalah gaya kepemimpinan demokratis.
\end{abstract}

Kata Kunci: Kompetensi manajerial, Kepala sekolah, Profesionalisme guru

\section{PENDAHULUAN}

Pendidikan adalah usaha sadar yang dilakukan oleh orang dewasa (pendidik) dalam menyelenggarakan kegiatan pembangunan diri peserta didik agar menjadi manusia paripurna sesuai dengan tujuan yang telah ditentukan sebelumnya. Pendidikan bisa membantu manusia mengangkat harkat dan martabatnya dibandingkan manusia lain yang tidak berpendidikan (Kompri:2015).

Kompetensi adalah suatu seperangkat pengetahuan, keterampilan, dan perilaku yang harus dimiliki, dihayati, dan dikuasai oleh guru, dan dosen dalam melaksanakan tugas keprofesionalannya. (UU. Guru dan dosen No 14:2005). Kompetensi sebagaimana disebutkan oleh Len Holmes menyebutkan bahwa" $a$ competence is a description of something wich a person mhi works in a given occupational areashould be able to do. It is description of an action, behavior or outcome which a person should be able to demonstrate (E.Mulyasa:2007). Kompetensi adalah suatu kemampuan atau kapasitas seseorang untuk melakukan berbagai tugas dalam suatu pekerjaan dimana kemampuan tersebut ditentukan oleh faktor intelektual dan fisk. (Stephen robbyn:2007).

Manajerial merupakan kata sifat yang berhubungan dengan kepemimpinan dan pengelolaan. Dalam banyak kepustakaan, kata manajerial sering disebut sebagai asal kata dari management yang berarti melatih kuda atau secara harfiah diartikan sebagai to handle yang berarti mengurus, menangani, atau mengendalikan. Manajemen merupakan kata benda yang dapat berarti pengelolaan, tata pimpinan atau ketatalaksanaan. (Nanang fatah:2000). Dalam penelitian yang berjudul Identifikasi Faktor-Faktor Kemampuan Manajerial yang Diperlukan Dalam Implementasi School Based Manajemen (SBM) dan Impementasinya Terhadap Program Pembinaan Kepala Sekolah, menyatakan bahwa definisi kemampuan manajerial adalah seperangkat keterampilan teknis dalam melaksanakan tugas sebagai manajer sekolah untuk mendayagunkan segala sumber yang 
tersedia untuk mencapai tujuan sekolah secara efektif dan efesien. (Akdon : 2002).

Kepala sekolah merupakan sosok kunci dari sebuah sistem manajemen sekolah. Hal ini memberikan arti bahwa sosok kepala sekolah harus mampu manjaga iklim positif yang ada di sekolah, mendorong guru-guru untuk bersemangat dalam meningkatkan kompetensinya, merangkul semua stafnya agar dapat bekerja dengan baik sehingga kondisi lingkungan sekolah menjadi nyaman dan yang paling penting peran kepala sekolah adalah dapat mendorong para siswa untuk memiliki prestasi yang gemilang. (Agustini, 2017).

Kepala sekolah sebagai seorang tenaga fungsional guru yang diberi tugas untuk memimpin suatu sekolah dimana diselenggarakan proses belajar mengajar, atau tempat dimana terjadi interaksi antara guru yang memberi pelajaran dan murid yang menerima sebuah pelajaran. (Wahjosumidjo:2003). Profesionalisme merupakan sebutan yang mengacu pada sikap mental dalam bentuk komitmen dari para anggota suatu profesi untuk senantiasa mewujudkan dan meningkatkan kualitas profesionalannya (Muhammad Surya, 2007: 14).

Peningkatan kualitas pendidikan merupakan suatau proses yang terintregasi dengan proses peningkatan kualitas sumber daya manusia itu sendiri. Menyadari pentingnya proses peningkatan kualitas sumber daya manusia, pemerintah bersama kalangan negeri terus berupaya mewujudkan amanah tersebut melalui berbagai usaha pembangunan pendidikan yang lebih berkualitas pada kenyataannya upaya pemerintah tersebut belum cukup dalam meningkatkan kualitas pendidikan Indonesia lalu upaya apa lagi untuk meningkatkan kualitas pendidikan Indonesia ? Disilah tantangan sekaligus peluang bagi pengelola lembaga pendidikan untuk mampu merealisasikan harapan orang tua dan masyarakat tersebut, tentunya setiap lembaga harus memiliki strategi untuk meningkatkan kualitas pendidikannya. SMAN 1 merupakan sekolah rujukan di kabupaten pamekasan Penelitian ini dilakukan atas dasar alasan yaitu Prestasi akademik dan non akademik yang selama ini dicapai oleh SMAN 1 Pamekasan tentunya tidak lepas dari peran kepala sekolah dalam mengeksplorasi dan memberdayakan segala potensi yang ada di sekolah, terutama dalam mengembangkan dan meningkatkan profesionalisme guru.

\section{METODE}

Penelitian ini menggunakan pendekatan deskriptif kualitatif. Penelitian bertujuan untuk mendeskripsikan dan menganalisis kebudayaan suatu organisasi secara fenomologis dan apa adanya. Lokasi penelitian ini dilakukan di SMAN 1 Pamekasan. Instrumen yang digunakan dalam penelitian ini adalah wawancara, observasi dan dokumentasi. Sedangkan analisisnya peneliti menggunakan analisis deskriptif. Yaitu berupa data-data tertulis atau lisan dari informan, dan perilaku yang diamati. sumber data yang penulis teliti untuk kemudian dianalisa berupa sumber primer yakni kepala sekolah dan guru. Dan sumber sekunder berupa jurnal guru sebagai refrensi, dokumen-dokumen penting lainnya.

\section{HASIL DAN PEMBAHASAN}

SMA Negeri 1 Pamekasan, dibentuk pada tahun 1948. Sekolah ini terletak di pusat kota Pamekasan yang saat itu beralamat di Jl. Slamet Riyadi No.1 Dan merupakan satusatunya sekolah SMA di Madura saat itu. Sekolah ini telah melahirkan banyak tokoh diantaranya Jenderal R. Hartono (Mantan KSAD dan Mantan Menteri Penerangan saat Presiden Soeharto). Dalam sebuah visi misi nya bahwa untuk mencetak generasi bangsa (tamatan pendidikan) yang berkualitas mampu mewujudkan insan yang beriman dan bertaqwa kepada Tuhan Yang Maha Esa, berakhlak mulia, cerdas, peduli lingkungan serta mampu menjawab tantangan zaman. Sedangkan di lihat dari misinya untuk menghasilkan tingkat profesionalisme guru ialah mewujudkan tenaga pendidik dan tenaga kependidikan yang profesional serta berwawasan lingkungan hidup, meningkatkan kualitas sumber daya manusia yang dapat berkompetisi baik lokal maupun global. Seiring perjalanan waktu, seiring pula dengan perkembangan zaman. SMAN 1 Pamekasan dengan segala prestasi dan keunggulannya berstatus sebagai sekolah kategori mandiri tahun 2017, sekolah standart 
nasional tahun 2008, sekolah RSBI tahun 2009 2014.

Dalam kompetensi manajerial kepala sekolah dalam peningkatan profesionalisme guru perencanaan diantaranya mengikutsertakan guru-guru dalam pengembangan profesi ke luar kota ataupun di dalam sekolah sendiri. Seperti halnya workshop atau pelatihan, dari sekolah sendiri ada workshop tentang kelas berfikir kritis,menganalisa dalam kontekstual karena SMAN 1 Pamekasan menjadi sekolah rujukan. Kegiatan-kegiatan tersebut terus dilakukan secara berkelanjutan. Dan yang terakhir melakukan supervisi dari kepala sekolah.dilakukan dua kali dalam tiap semester. Dan dalam faktor pendukung dan penghambat terkait hal ini (kompetensi manajerial dalam meningkatkan profesionalisme guru) pertama sekolah tetap menggunakan aturan terhadap UU SISDIKNAS tentang delapan standart nasional. Tergantung juga kondisi real sekolah hal apa yang harus dsekolah dikelola secara efektif dan efesien. Dalam hal ini ada dua faktor yakni internal (kebijakan kepala sekolah) dan eksternal (UU,peraturan menteri ,pemerintah).

Kompetensi kepala sekolah yang sangat teknikal adalah kompetensi manajerial. Dengan demikian, apabila seseorang sudah menjadi kepala sekolah, khalayak memandang bahwa orang tersebut memiliki kompetensi manajerial secara baik. Menurut George R. Terry, 1958, Principles of Management (Sukarna, 2011: 10) terdapat empat fungsi dasar manajemen, yaitu Planning (Perencanaan), Organizing (Pengorganisasian), Actuating (Pelaksanaan), dan Controlling (Pengawasan).

Kepala sekolah sangat disiplin dan bijaksana dalam melakukan suatu keputusan secara musyawarah, menjaga betul peran dan fungsinya. dalam hal penerapan kepemimpinan menetapkan sebuah kebijakan secara musyawarah bersama, sehingga setiap memimpin rapat beliau tidak mengambil keputusan secara sepihak melainkan masih memberi peluang kepada pengikutnya yang lain yakni guru dan staf nya. Disamping itu kemampuan tingkat spiritualnya sangat baik. Ada tiga komponen dalam menjalankan kegiatan yakni, Perencanaan, Pelaksanaan, dan Evaluasi. Di awal ajaran baru menetapkan analisis kebutuhan guru sesuai tupoksinya. Mempersiapkan kurikulum nya, perencanaan pelatihan-pelatihan (workshop), menyusun program tahunan (prota), program semester (promes) setelah itu jalan ada tagihan yaitu prota promis, memberikan agenda akademik, adanya KBM sesuai perencaan daripada guru kemudian ada kegiatan melakukan supervisi, setelah hasil supervisi dilakukan lanjut evaluasi.

Gaya kepemimpinan kepala sekolah di SMAN 1 Pamekasan menerapakan tipe gaya kepemimpinan demokratis, semua putusan beliau putuskan melalui musyawarah dan mufakat bersama. Karena gaya kepemimpinan kepala sekolah dalam meningkatkan profesionalisme guru sangat berpengaruh besar dan menjadi faktor penting terhadap kualitas pendidikan di SMAN 1 Pamekasan.

Adapun input pendidikan lainnya yakni perangkat lunak yang telah di sajikan untuk sekolah agar bisa menghasilkan sekolah yang bermutu dan mencetak guru-guru yang profesionalisme. Dalam Peraturan Pemerintah No 19 Tahun 2005 tentang standar nasional Pendidikan menyebutkan tenaga kependidikan sekurang-kurangnya terdiri atas kepala sekolah, tenaga administrasi, tenaga perpustakaan, tenaga laboratorium, dan tenaga kebersihan sekolah. Kemudian dalam Undangundang No 20 tahun 2003 menyebutkan bahwasannya tenaga kependidikan bertugas melaksanakan administrasi pengelolaa, pengembangan, pengawasan dan pelayanan teknik untuk menunjang proses pendidikan pada satuan pendidikan.

Seperti halnya struktur organisasi sekolah, peraturan perundang-undangan, perencanaan, deskripsi tugas dan programprogram. Kemudian di lihat dari proses pendidikan di sekolah SMAN 1 Pamekasan, baik dari proses pengambilan keputusan, proses pengelolaan kelembagaan, proses pengelolaan program, proses belajar mengajar dan proses monitoring, dan evaluasi sangat dikuasi dan di realisasikan dengan baik. Pengkoordinasiannya dan penyerasiannya serta pemanduan input sekolah (guru, siswa, kurikulum, keuangan, peralatan, dan sebagainya) dilakukan oleh seluruh staf dan kepala sekolah secara harmonis dan didasari kekeluargaan, sehingga mampu 
menciptakan situasi pembeljaran yang menyenangkan (enjoyeble learning), mampu mendorong motivasi dan minat belajar dan mampu memperdayakan peserta didik dengan landasan IMTAQ dan IPTEQ.

Output di sekolah SMAN 1 Pamekasan, banyak prestasi-prestasi yang telah di raih oleh peserta didik, dan banyak program-program sekolah yang yang terealisasi dan bersaing dengan berbagai sekolah di tingkat kabupaten, nasional bahkan tingkat internasional. Di dalam ruang tamu, berjejeran bermacam-macam piagam ,sertfikat dan tropy baik dari sekolah maupun peserta didik. Hal ini sudah bisa menunjukkan pencapaian yang luarbiasa dalam prestasi akademik (karya-kartya ilmiah,lombalomba) dan prestasi non-akademik (olahraga,kesenian dan kegiatan ekstrakurikuler lainnya. di SMAN 1 Pamekasan menggunakan kurikulum k-13.

Kemampuan manajerial kepala sekolah dalam peningkatan profesionalisme guru di SMAN 1 Pamekasan, hal ini sangat berpengaruh ketika peneliti memperhatikan gerakan top down dan button up kepala sekolah, karena gerakan top down dan kerja keras tersebut memberikan contoh terbaik, sedangkan button up memberikan penguasaan bidang keilmuan, pengetahuan dan ketrampilan yang terus bertambah dan berkembang pada guru-guru itu sendiri.

Kepala sekolah dalam menjalankan tugasnya tentu tidak sendiri. Dengan kemampuan manajerial dimilikinya, kepala sekolah diharapkan bisa memperdayakan seluruh guru dan stafnya untuk menjalankan sistem sekolah untuk menjacapai visi yang telah ditetapkan. Kecakapan kepala sekolah berdasarkan Peraturan Menteri Pendidikan Nasional Nomor 13 Tahun 2007 tentang Standar Kepala Sekolah/ Madrasah adalah kompetensi kepribadian, kompetensi manajerial, kompetensi kewirausahaan, kompetensi supervisi, dan kompetensi sosial (Litbang Kemdikbud, 2013).

Kepemimpinan dalam penerapan
manajemen sekolah memerlukan dua keterampilan yaitu keterampilan memimpin dan keterampilan mengelola (kepemimpinan dan manajerial). Perilaku kepemimpinan dalam melaksanakan keterampilan ini memegang peranan yang sangat penting untuk untuk meningkatkan kualitas sekolah. Perilaku kepemimpinan yang positif dan mendukung terhadap penerapan manajemen kepala sekolah akan lebih mencapai keberhasilan. Hasil penelitian Douglas \& Hakim (2001), menemukan bahwa sebagian besar pemimpin yang hanya memberikan pelayanan untuk peningkatan kualitas tanpa ada perilaku yang mendukung, mengurangi keberhasilan pelaksanaan hasil manajemen kepala sekolah.

Keberhasilan Suatu organisasi atau lembaga dipengaruhi oleh berbagai faktor, Dari berbagai faktor tersebut, faktor internal yang paling penting seperti mengikutsertakan guruguru dalam pelatihan atau workshop sehingga guru mampu mengembangkan keilmuan dan kemampuan nya. Perencanaan program tahunan ataupun program semester dengan baik dan bisa dipertanggung jawabkan. Karena profesionalisme seseorang itu tergantung dengan dipengaruhi (1) kualifikasi akademik dan (2) Waktu yang lama dalam menjabat. Kemudian peran dari kepala sekolah ialah memberikan motivasi kepada seluruh warga sekolah. Karena motivasi merupakan suatu faktor yang cukup dominan dan dapat menggerakkan faktor-faktor lain ke arah efektivitas kerja.

Semua guru di sekolah bekerja untuk mencapai tujuan bersama. Semua putusan diambil melalui musyawarah dan mufakat serta harus ditaati. Pemimpin menghormati dan menghargai pendapat tiap-tiap guru dan memberi kesempatan kepada guru-guru untuk mengembangkan inisiatif dan daya kreatifnya. Pemimpin demokratis tidak melaksanakan tugasnya senidiri, ia bersifat bijaksana di dalam pembagian pekerjaan dan tanggung jawab. Kompetensi manajerial kepala sekolah yang efektif mencerminkan pemantauan, visioner, transformasional, rencana jangka panjang, membangun jaringan kerja dengan pelanggan eksternal, inovatif, dan kreatif.

Kepala sekolah sudah memimpin SMAN 1 Pamekasan selama kurang lebih empat tahun hal ini karena dalam kepemimpinan bagus dan dipercaya, sesosok pemimpin yang religius, memimpin karena faktor bakat dan gen, maka hal tersebut termasuk teori ekologis. Teori 
ekologis ini pada intinya berarti bahwa seseorang hanya akan berhasil menjadi pemimpin yang baik apabila ia telah memiliki bakat kepemimpinan. Bakat kepemimpinan tersebut dikembangkan melalui pendidikan yang teratur dan pengalaman yang memungkinkan untuk dikembangkan lebih lanjut. (Yasmil Anwar \& Sadang)

Input pendidikan adalah segala sesuatu yang harus tersedia karena dibutuhkan untuk berlangsungnya proses. Sesuatu yang dimaksud berupa sumber daya dan perangkat lunak serta harapan-harapan sebagai pemandu bagi berlangsungnya proses. Input sumber daya meliputi sumber daya manusia ( kepala sekolah, guru termasuk guru BP, Karyawan, siswa) dan sumber daya selebihnya (peralatan, perlengkapan, uang, bahan, dan sebagainya.)

Melakukan supervisi setiap semester dan tiap tahunnya. Disamping sebagai supervisor, kepala sekolah juga harus mampu menjadi evaluator bagi program-program yang telah dilaksnakan. Evaluasi sangat perlu dilakukan untuk mempengaruhi tingkat pencapaian tujuan yang telah ditetapkan sebelumnya. Semua pelaksanaan dari rencana kerja yang telah terwujud secara berkala harus dievaluasi. Evaluasi diperlukan agar penyimpanganpenyimpangan bisa dihindarkan serta untuk menjamin tercapainya tujuan. Kepala sekolah SMAN 1 Pamekasan telah melakukan evaluasi satu kali dalan sebulan atau kondisional jika keadaan mendesak baik pada guru-guru, karyawan-karyawan ,siswa-siswi, proses pembelajaran yang ada diruang lingkup sekolah.

\section{KESIMPULAN}

Berdasarkan hasil penelitian Kompetensi manajerial kepala sekolah dalam meningkatkan profesionalisme guru dapatt diambiul kesimpulan sebagai berikut : Penerapan kepemimpinan yang diterapkan oleh Kepala sekolah di SMAN 1 Pamekasan bahwasanya berpegang teguh pada tiga pola dasar, yakni perencanaan, pengembangan, dan evaluasi. Perilaku kepemimpinan kepala sekolah yang efektif tertib administrasi sehingga selalu mengambil keputusan dengan berdasarkan data organisasi yang jelas, bukan suatu gambaran atau perkiraan. Kemudian faktor pendukung dalam meningkatkan profesionalisme guru di SMAN 1 Berlandaskan dari faktor Internal yakni kinerja, motivasi, pelatihan-pelatihan pada guru, dan kebijakan kepala sekolah sesuai kondisi real sekolah. dan faktor eksternal yakni kebijakan pemerintah/UU, delapan standart SISDIKNAS. Karena profesionalisme seseorang itu tergantung dengan dipengaruhi pertama, kualifikasi akademik dan kedua,Waktu yang lama dalam menjabat. Gaya kepemimpinan yang diterapkan oleh Kepala SMAN 1 Pamekasan adalah gaya kepemimpinan demokratis.

\section{SARAN}

BeSrdasarkan kesimpulan dan data yang dtitemukan di lapangan, peneliti memberikan saran yang perlu di sampaikan kepada pihak terkait yakni: (1). Kepala sekolah harus lebih optimalkan dalam mengimplementasikan kompetensi manajerial secara keseluruhan agar tercapainya kualitas sekolah. (2). Kepala sekolah secara berkelanjutan terus mengembangkan potensi yang dimiliki oleh guru-guru dan terus mengembangkan pemberdayaan SDM. (3). Kepala sekolah lebih mampu mengendalikan faktor-faktor pendukung dan penghambat dalam menerapkan kompetensi manajerialnya sehingga berjalan secara efektif dan efesien.

\section{DAFTAR PUSTAKA}

Anton, A. (2013). Dasar-dasar Manajemen, Bandung: PT Pustaka setia

Atiqullah. (2010). Manajemen \& Kepemimpinan Pendidikan Islam, Pamekasan: STAIN Pmk Press

Badeni, Kepemimpinan dan perilaku organisasi. Bandung: Alfabeta.

Chulsum, Umi dan Novia, Windy. (2006). Kamus Besar Bahasa Indonesia, Surabaya: Kashiko

E.Mulyasa. (2011). Menjadi Kepala Sekolah Profesonal, Bandung: Remaja Rosdakarya,

Efendi Nur. (2015 ). Islamic Educational Leadership, Yogyakarta: Kalimedia 
Hadi Sutrisno. Metodologi Research, Yogyakarta: Yayasan penerbitan Fakultas Psikologi UGM.

Jurnal Idaarah, Vol. I, No. 2, Desember 2017

Kartini Kartono. (1986). Pengantar Metodologi riset sosial, Alumni bandung

Kitab Al-qur'an, 4 (An-Nisa'): 5

Kompri. (2015). Manajemen Pendidikan, Yogyakarta: PT Arruz Media

Majid, Abdul, (2011). Perencanaan Pembelajaran, Mengembangkan Standar Kompetensi Guru, Bandung: PT. Remaja Rosdakarya

Minarti Sri. (2016). Manajemen Sekolah Mengelola Lembaga Pendidikan Secara Mandiri, Jogjakarta: Arruz media

Muin, A dan Nurhalima, (2016). Kepemimpinan Pendidikan, Malang: Ismaya Berkah Group

Nasir Moh. (1988). Metode Penelitian, Jogjakarta: PT Ghalia Indonesia, 1988.

Peraturan Menteri Pendidikan Nasional Nomor 13 Tahun 2007 tentang Standar Kepala Sekolah/Madrasah terdiri dari 5 kompetensi.

Peraturan Menteri Pendidikan Nasional Nomor 16 Tahun 2007 standar Kualifikasi Akademi dan Kompetensi Guru.

Peraturan Menteri Pendidikan Nasional tentang standar kepala sekolah/madrasah Nomor 13 Tahun 2007.

Rosady, R. (2004). Metode Penelitian Public Relation Dan Komunikasi, Jakarta: PT. Raja Grafindel Persada

S.e.,M.M Amirullah. (2013). Pengantar Manajemen, Yogyakarta: Mitra Wacana Media

Soekarto Indrafachrudi.

(1993:33

Kepemimpinan Pendidikan,

Sudirga. (2006: 25). Pendidikan Ki hajar dewantara

Sugiono. (2016). Metodologi Penelitian Kuantitatif Kualitatif dan $R \& D$, Bandung: Alfabeta
Sugiyono. (2005). Memahami Penelitian Kualitatif, Bandung: PT Alfabeta

Tilaar. (2006). Strandarisasi Pendidikan Nasional, Jakarta: Rineka Cipta

Uzer Usman, Moh. (2013). Menjadi Guru Profesional, Bandung: Remaja Rosdakarya,

Wahjosumidjo, (2013). Kepemimpinan Kepala Sekolah. Tinjauan Teoritik dan Permasalahannya, Jakarta: Rajawali Pers

Yasmil Anwar dan Adang. Sosiologi Untuk Universitas, Bandung: PT,Refika Aditama 